\section{Assessing 'Bing' Sweet Cherry Tolerance to a Heated Controlled Atmosphere for Insect Pest Control}

\author{
K.C. Shellie, ${ }^{1}$ L.G. Neven, ${ }^{2}$ \\ and S.R. Drake 3
}

Additional index words. disinfestation, methyl bromide, hot forced air, fumigation, quality, postharvest

Summary. Sweet cherries (Prunus avium 'Bing') exposed to 113 or 117 ${ }^{\circ} \mathrm{F}\left(45\right.$ or $\left.47^{\circ} \mathrm{C}\right)$ in an atmosphere of $1 \%$ oxygen with $15 \%$ carbon dioxide (balance nitrogen) were heated to a maximum center temperature of 112 or $115^{\circ} \mathrm{F}\left(44\right.$ or $\left.46^{\circ} \mathrm{C}\right)$ in 41 or 27 min, respectively. Heated cherries had similar incidence of pitting and decay, and similar preference ratings after 14 days of storage at $34^{\circ} \mathrm{F}\left(1^{\circ} \mathrm{C}\right)$ as nonheated or methyl bromide fumigated fruit. Heated cherries and methyl bromide fumigated cherries were less firm after 14 days of cold storage than nonheated, control fruit. The stems of methyl bromide fumigated cherries were less green than heated or nonheated cherries. Cherries

\footnotetext{
We acknowledge partial financial support by the Washington Tree Fruit Research Commission; technical assistance of Carlos Solis (TransFresh Corp.), Barbara Blaisdell, Donald Staiff, and Shari Snodgrass (USDAARS Wenatchee, Wash.); and logistical support by Gene Kupferman (WSU Wenatchee), Kyle Mathison and A. Nathan Reed (Stemilt Growers, Inc. Wenatchee). Mention of trademark, proprietary product, or vendor does not constitute a guarantee or warranty of the product by the U.S. Dept. of Agriculture and does not imply its approval to the exclusion of other product or vendors that also may be suitable. The cost of publishing this paper was defrayed in part by the payment of page charges. Under postal regulations, this paper therefore must be hereby marked advertisement solely to indicate this fact.

${ }^{1}$ U.S. Department of Agriculture, Agricultural Re search Service, 2413 E. Highway 83, Building 200 Weslaco, TX 78596.

${ }^{2}$ U.S. Department of Agriculture, Agricultural Research Service, 5230 Konnowac Pass Rd Wapato, WA 98951-9651.

${ }^{3}$ U.S. Department of Agriculture, Agricultural Re search Service, 1104 N. Western Ave. Wenatchee, WA
} 98801-0000. exposed to $113{ }^{\circ} \mathrm{F}$ had lower titratable acidity than nonheated cherries, fumigated cherries, or cherries exposed to $117^{\circ} \mathrm{F}$. Cherry quality after 14 days of cold storage was not affected by hydrocooling before heating $\left(5 \mathrm{~min}\right.$ in water at $34^{\circ} \mathrm{F}$ ) or by method of cooling after heating (hydrocooling, forced air cooling, or static air cooling). Cherries stored for 14 days at $34{ }^{\circ} \mathrm{F}$ in $6 \%$ oxygen with $17 \%$ carbon dioxide (balance nitrogen) had similar market quality as cherries stored in air at $34^{\circ} \mathrm{F}$. Results suggest that 'Bing' sweet cherry can tolerate heating in an atmosphere of low oxygen containing elevated carbon dioxide at doses that may provide quarantine security against codling moth (Cydia pomonella) and western cherry fruit fly (Rbagoletis cingulata).

$M$ ost U.S. fresh-market sweet cherries are grown in the states of Washington, Oregon, and California. About 30\% [13,655 tons (12,390 t) $]$ of production, having an estimated value of \$61 million, was exported to Japan in 1997. Japan and some U.S. domestic destinations have phytosanitary restrictions against codling moth and western cherry fruit fly, requiring cherries to be treated before shipment to ensure all fruit are free of viable insects. Fumigation with methyl bromide had been the treatment of choice, in spite of deleterious effects on cherry fruit market quality (Drake et al., 1991). In 1992 methyl bromide was identified as a Class I ozone depleting substance (United Nations Environmental Programme, 1992). The 1998 amendment to the 1990 U.S. Clean Air Act grants exemption for quarantine and preshipment, and harmonizes importation and production restrictions with the 2005 phaseout plan of the Montreal Protocol. The Methyl Bromide Technical Options Committee (USDA, 1999) reported that in $1996,22 \%$ of global methyl bromide usage, or 15,000 tons $(13,600$ $\mathrm{t}$ ), was for the purpose of quarantine and preshipment. Exemption could be relinquished in the near future if scale of use is found to conflict with global environmental goals. Even if quarantine and preshipment remain exempt, the cost of methyl bromide will likely increase as supply becomes more limited. Increased costs, uncertain availability, and documented deleterious effects on cherry fresh market quality have all stimulated interest by the fresh market sweet cherry industry to identify alternative ways of meeting insect phytosanitary requirements.

Codling moth can survive for up to $24 \mathrm{~d}$ at $77^{\circ} \mathrm{F}\left(25^{\circ} \mathrm{C}\right)$ in an oxygen depleted and/or carbon dioxide enriched atmosphere (Soderstrom et al., 1990). However, the length of time the fruit need to be exposed to a controlled atmosphere can be reduced from weeks to hours by increasing the temperature of the oxygen-depleted, carbon dioxide-enriched atmosphere from 77 to 111 or $115^{\circ} \mathrm{F}\left(44\right.$ or $46^{\circ} \mathrm{C}$ ) (Neven and Mitcham, 1996). For a similar heat dose, internal feeding insects were killed 30 to $40 \%$ faster when the fruit was heated in a low oxygen and/or high carbon dioxide atmosphere compared to heating in air (Neven and Mitcham, 1996; Shellie et al., 1997). The doses established for commodity treatments must optimize fruit market quality attributes while satisfying phytosanitary pest requirements. The objective of this research was to evaluate the impact of high temperature controlled atmosphere treatments for quarantine security against codling moth and western cherry fruit fly on fresh market quality of 'Bing' sweet cherry. The influence of hydrocooling before and after heating, and of controlled atmosphere refrigerated storage after heating on fruit quality attributes was also evaluated.

\section{Materials and methods}

'Bing' cherries (50 lb (22.7 kg)) were harvested in the early morning of two consecutive days from the same grower lot on Stemilt Hill in Wenatchee, Wash. during the weeks of 12 July and 19 July 1999. Cherries were harvested into plastic lugs and immediately transported in an air-conditioned van (less than $20 \mathrm{~min}$ ), to the Agricultural Research Service research facility in Wenatchee, Wash. Upon arrival at the research facility, the cherries were divided into three lots of about $15 \mathrm{lb}(6.8$ $\mathrm{kg}$ ) each. Two lots were immediately hydrocooled for $5 \mathrm{~min}$ with water at 34 ${ }^{\circ} \mathrm{F}$. Cherries not immediately hydrocooled received a heat treatment. When the heat treatment of the nonhydrocooled lot was completed, an identical heat treatment was delivered to one of the hydrocooled lots. The remaining hydrocooled lot served as a control. On the day of harvest, $7 \mathrm{lb}(3.2$ $\mathrm{kg}$ ) of hydrocooled, nonheated cherries 
were fumigated with methyl bromide at $64 \mathrm{~g} \cdot \mathrm{m}^{-3}\left(4 \mathrm{lb} / 1000 \mathrm{ft}^{3}\right)$ for $2 \mathrm{~h}$ at $43^{\circ} \mathrm{F}$ $\left(6^{\circ} \mathrm{C}\right)$ in a commercial fumigation chamber together with a load of cherries destined for export. The morning after fumigation, the fumigated experimental cherries were retrieved from the commercial fumigation room and thereafter handled similar to control and heattreated fruit.

Heat-treated cherries received one of two heat treatments delivered in an atmosphere of $1 \%$ oxygen $\left(\mathrm{O}_{2}\right)$ and $15 \%$ carbon dioxide $\left(\mathrm{CO}_{2}\right)$ (balance nitrogen). Fruit harvested from a grower lot on the first day were exposed to $113^{\circ} \mathrm{F}$, and fruit harvested from the same grower lot on the second day were exposed to $117^{\circ} \mathrm{F}$. This experimental design was replicated 4 times comprising a total of eight fruit harvests from four different grower lots.

Heat was delivered to the cherries inside a stainless steel chamber that forced heated gas, at a velocity of $2 \mathrm{~m} \cdot \mathrm{s}^{-1}(6.6$ $\mathrm{ft} / \mathrm{s})$, up vertically through four, vented bottom, solid-sided plastic lugs (TechniSystems Chelan, Wash.). The cherries were placed, single layer deep in the uppermost three lugs, into an ambient temperature (about $75^{\circ} \mathrm{F}\left(24^{\circ} \mathrm{C}\right)$ ) chamber. A temperature probe was inserted into the center of two cherries and just under the skin of a third cherry in each of the three treatment lugs. A fourth lug of single-layer deep cherries was placed in the bottom (hottest) position of the treatment chamber to enhance temperature uniformity among the uppermost three treatment lugs, and was discarded after each heat treatment. The chamber was sealed, and an atmosphere of $1 \% \mathrm{O}_{2}$ and $15 \% \mathrm{CO}_{2}$ was established inside. Heating was initiated after the atmosphere was established. Heating was terminated after cherries were exposed to a chamber atmosphere temperature of 113 or $117^{\circ} \mathrm{F}$ for 35 or $20 \mathrm{~min}$, respectively. Total treatment time was calculated as the sum of minutes required for the chamber atmosphere to reach its set point temperature of 113 or $117^{\circ} \mathrm{F}$, and the 35 or $20 \mathrm{~min}$, respectively, that the cherries were exposed to the chamber atmosphere at set point temperature. Atmosphere control inside the chamber was monitored continuously with flow-through ana- lyzers automated by computer controlled solenoid valves that regulated the introduction of component gases from pressurized cylinders. A chilled mirror type, dew point hygrometer (EG \& G, Waltham, Mass.) was used to measure dew point temperature inside the chamber, and control was maintained at $3.6^{\circ} \mathrm{F}\left(2^{\circ} \mathrm{C}\right)$ cooler than the coolest cherry fruit surface by computer controlled injection of atomized water from a pressurized water reservoir. Center and surface temperature of probed cherries, and chamber dew point temperature, supply and return air temperature, $\mathrm{CO}_{2}$ and $\mathrm{O}_{2}$ concentration, and air

Fig. 1. Average center temperature of 'Bing' cherry during exposure to $1 \%$ $\mathrm{O}_{2}$ with $15 \% \mathrm{CO}_{2}$ (balance nitrogen) at 113 or $117^{\circ} \mathrm{F}\left(45\right.$ or $\left.47^{\circ} \mathrm{C}\right)$. Solid symbols represent average value of 48 cherries during eight treatment applications in 1999 with chamber heating initiated at time 0. Open symbols represent average center temperature of cherries loaded into a preheated treatment chamber in quality analyses reported by Neven and Drake (2000); ${ }^{\circ} \mathrm{C}=5 / 9\left({ }^{\circ} \mathrm{F}-32\right)$.

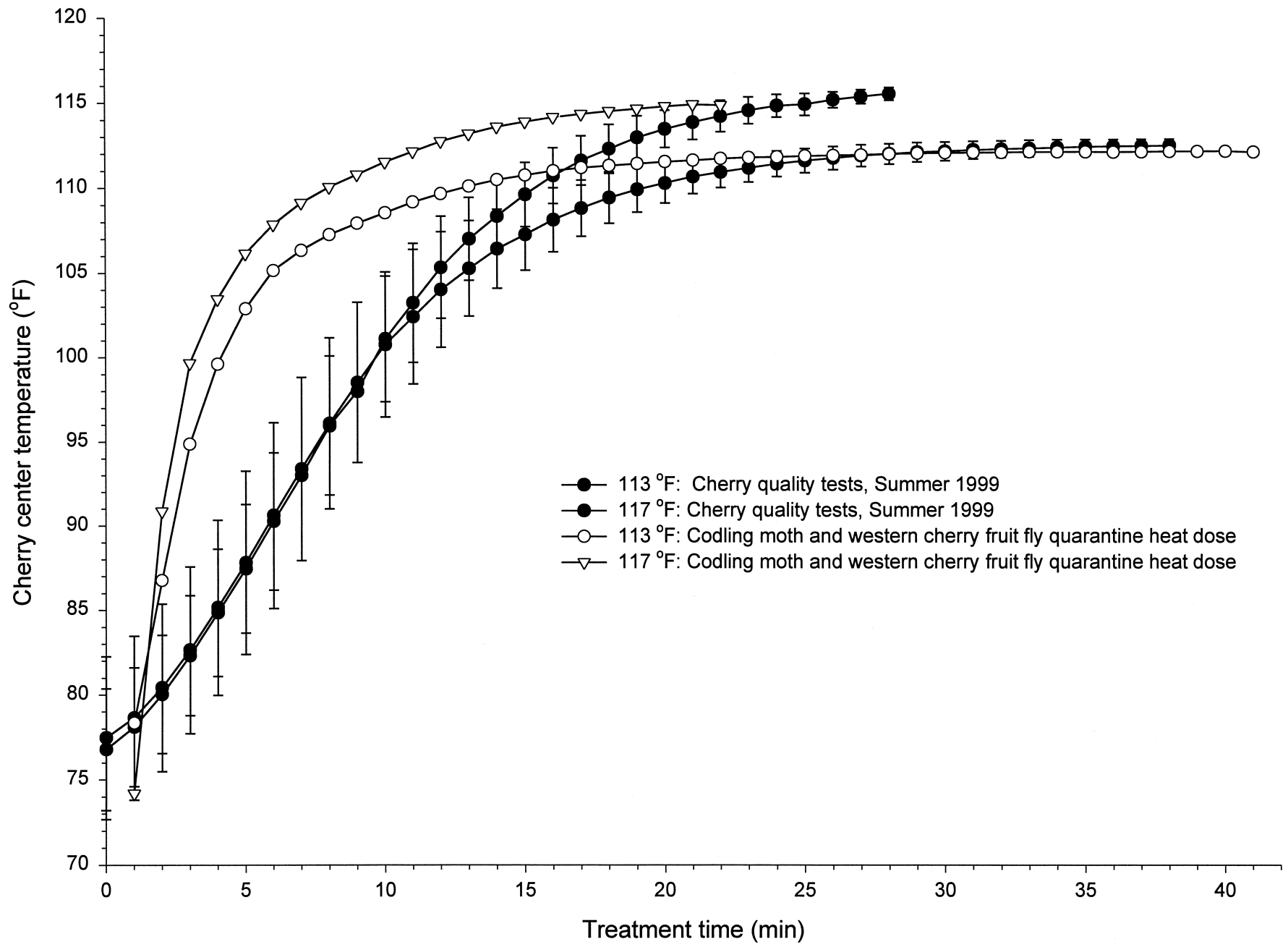


Table 1. Quality attributes of 'Bing' sweet cherry after $14 \mathrm{~d}$ of storage in air at $34{ }^{\circ} \mathrm{F}\left(1.1^{\circ} \mathrm{C}\right)$. On the day of harvest, cherries were exposed to 113 or $117^{\circ} \mathrm{F}\left(45\right.$ or $\left.47^{\circ} \mathrm{C}\right)$ in an atmosphere of $1 \% \mathrm{O}_{2}$ with $15 \% \mathrm{CO}_{2}$ (balance nitrogen), fumigated with methyl bromide, or left untreated $\left[{ }^{\circ} \mathrm{C}=5 / 9\left({ }^{\circ} \mathrm{F}-32\right) ; 1.0 \mathrm{~g} \cdot \mathrm{mm}^{-2}=2.2 \mathrm{oz} / \mathrm{inch}^{2}\right]$.

\begin{tabular}{|c|c|c|c|c|c|c|c|c|c|c|}
\hline Parameter & $113^{\circ} \mathrm{F}$ & $117^{\circ} \mathbf{F}$ & $113^{\circ} \mathrm{F}$ & $117^{\circ} \mathbf{F}$ & $113^{\circ} \mathrm{F}$ & $117^{\circ} \mathbf{F}$ & $113^{\circ} \mathrm{F}$ & $117^{\circ} \mathrm{F}$ & $113^{\circ} \mathrm{F}$ & $117^{\circ} \mathrm{F}$ \\
\hline Heat & $96.8 \mathrm{a}$ & $119.5 \mathrm{a}$ & $13.3 \mathrm{a}$ & $11.2 \mathrm{a}$ & $5.0 \mathrm{a}$ & $6.6 \mathrm{a}$ & $191.02 \mathrm{a}$ & $232.89 \mathrm{a}$ & $0.7156 \mathrm{a}$ & $0.8226 \mathrm{a}$ \\
\hline Methyl bromide & $82.8 \mathrm{~b}$ & $72.5 \mathrm{~b}$ & $8.9 \mathrm{~b}$ & $8.7 \mathrm{a}$ & $5.4 \mathrm{a}$ & $5.6 \mathrm{a}$ & $176.61 \mathrm{a}$ & $220.01 \mathrm{a}$ & $0.7777 \mathrm{c}$ & $0.7908 \mathrm{a}$ \\
\hline
\end{tabular}

${ }^{\mathrm{z}}$ As hue angle decreases from 180, stem is less green.

y Rating by untrained preference panelists using a $9-\mathrm{cm}(3.6$ inch $)$ line scale with $\mathrm{l}=$ dislike extremely and $9=$ like extremely. Similar letters within a column indicate no significant difference at $P \leq 0.05$ using Duncans multiple range test.

${ }^{*, * \star}$ Significant at $P \leq 0.05$ or 0.01 , respectively.

velocity were logged by the computer every $60 \mathrm{~s}$ throughout the duration of each heat treatment.

After each heat treatment, all fruit in one of the top three lugs were either hydrocooled for $5 \mathrm{~min}$ in $34^{\circ} \mathrm{F}$ water, forced-air cooled for $5 \mathrm{~min}$ in air at 34 ${ }^{\circ} \mathrm{F}$, or left to cool for $30 \mathrm{~min}$ in static air at $80{ }^{\circ} \mathrm{F}\left(26.6^{\circ} \mathrm{C}\right)$. After cooling, the fruit within each treatment group were put into 3-lb (1.4-kg) cardboard cartons with plastic liners, and placed into sealed, plexiglass chambers inside a walkin refrigerator at $34^{\circ} \mathrm{F}$. The atmosphere inside the plexiglass chamber was maintained with air, or $6 \% \mathrm{O}_{2}$ with $17 \% \mathrm{CO}_{2}$ (balance nitrogen) in a flow-through system (TechniSystems Chelan, Wash.).

Cherry quality was evaluated after $14 \mathrm{~d}$ of storage at $34^{\circ} \mathrm{F}\left(1{ }^{\circ} \mathrm{C}\right)$. Incidence of decay within each carton was rated on a 0 to 4 scale with 0 corresponding to no decay, $1 \leq 15 \%, 2 \leq 50 \%$, $3 \leq 85 \%$, and $4 \leq 100 \%$ decayed fruit within each 3-lb carton. Pitting, stem color, external fruit color, fruit firmness, titratable acidity (TA), and soluble solids concentration (SSC) were determined on a random sample of 25 cherries from each treatment group. Incidence of pitting was estimated by dividing the number of pitted cherries in a 25 cherry sample by 25 and multiplying by 100 . Stem color was evaluated by removing the stems from 25 cherries, trimming both ends of the stem to yield a $3 \mathrm{~cm}$ (1.2 inch) long section of the center stem, and placing the 25 stems into a sample cup (\#11595;Agtron Magnuson Engineers Inc., San Jose, Calif.). Stem color was measured in the CIE LAB color scale by placing the sample cup over a 3-cm-diameter aperture of a $\mathrm{Pa}$ cific Instruments Color Machine (Pacific Scientific Co., Silver Spring, Md.). On each cherry in a 25 cherry sample, external fruit color was measured in the CIE LAB color scale with a Minolta chromometer, and firmness was measured in $\mathrm{g} \cdot \mathrm{mm}^{-2}$ using a FirmTechl (Bioworks, Stillwater, Okla). SSC and percent TA were determined on a composite sample of 25 cherries. The cherries were pitted and juice was extracted from the fruit flesh. Percent TA was determined by titrating $10 \mathrm{~mL}(0.3 \mathrm{fl}$ $\mathrm{oz}$ ) of a composite juice sample with 0.1 $\mathrm{N}$ sodium hydroxide to an endpoint $\mathrm{pH}$ of 8.2 , and calculation was based on malic acid equivalents (TTT 85 Titrator, Radiometer Copenhagen, Copenhagen, Denmark). SSC was determined by refractive index using an Abbe-type, temperature corrected refractometer.

A subjective assessment of cherry quality after $14 \mathrm{~d}$ of cold storage was obtained from untrained preference panelists who consumed cherries at three, independently randomized stations. The panelists marked a 1 to $9 \mathrm{~cm}(0.4$ to 3.6 inch), continuous line scale anchored with "dislike extremely" and "like extremely" corresponding to 1 and $9 \mathrm{~cm}$, respectively. Ratings were quantified by measuring distance, in $\mathrm{cm}$, from the extreme left of the line scale to the indicated preference mark.

The relative influence of methyl bromide fumigation and heating on fruit quality was evaluated by analyzing the data from each temperature dose with their corresponding fumigated and control fruit in an analysis of variance with four replications. The influence of hydrocooling before heating, cooling method after heating, and cold storage atmosphere on the fruit quality of heated cherries was evaluated by analyzing cherries heated at each dose with a 2 (precooling $) \times 3$ (cooling) $\times 2$ (cold storage atmosphere) factorial analysis of vari- ance with 4 replications. Duncan's multiple range test was used to separate mean values when a main effect was significant. SAS (SAS Institute Inc., Cary, N.C.) software was used for analysis.

\section{Results and discussion}

The fruit center temperature of cherries exposed to 113 or $117^{\circ} \mathrm{F}$ was still increasing when heat treatments were terminated after $41 \pm 1.6$ or $27 \pm$ $1.5 \mathrm{~min}$, respectively. The average maximum fruit center temperature of cherries exposed to 113 or $117^{\circ} \mathrm{F}$ was 112 or $115^{\circ} \mathrm{F}$, respectively. The chamber required $21 \pm 1.0 \mathrm{~min}$ to establish the desired $1 \% \mathrm{O}_{2}$ and $15 \% \mathrm{CO}_{2}$ atmosphere, and $6 \pm 1.2 \mathrm{~min}$ for the atmosphere to reach its set-point temperature. The maximum fruit center temperature obtained in this research was similar to that obtained in the research reported by Neven and Drake (2000), but the rate at which the cherries heated in this research was 6 min slower because Neven and Drake (2000) heated the atmosphere inside the chamber before loading the cherries (Fig. 1). We were not able to preheat the chamber because we lacked the necessary equipment to permit opening the exterior door to load the cherries without disrupting the desired atmosphere and temperature established inside the chamber. If a heated controlled atmosphere treatment were used on a commercial scale, we envision a flow-through type of application in which a belt containing cherries, single layer deep, would pause for the required duration (minutes) inside a sealed, preheated tunnel. A scale-up of this type of treatment application would most likely result in the faster of the two heating rates presented in Fig. 1.

Heat-treated and methyl bromide fumigated cherries were less firm after 
$14 \mathrm{~d}$ of cold storage than untreated controls (Table 1). Cherries heated in 113 or $117^{\circ} \mathrm{F}$ were $14 \%$ or $10 \%$ less firm, respectively than controls. Cherries fumigated with methyl bromide in each 113 or $117^{\circ} \mathrm{F}$ treatment group were $20 \%$ or $15 \%$ less firm, respectively than controls. Heat-treated and methyl bromide fumigated cherries had similar firmness after $14 \mathrm{~d}$ of cold storage. Neven and Drake (2000) reported similar reduction in firmness after heating or fumigating with methyl bromide. Hansen et al. (2000) also reported a $10 \%$ loss of firmness in methyl bromide fumigated 'Garnet' cherries.

The stems of heat-treated cherries had similar values for hue and chroma as controls (Table 1). However, the stem hue value of methyl bromide fumigated cherries was less green after $14 \mathrm{~d}$ of storage than heat-treated or control cherries. The stems of methyl bromide fumigated cherries also had lower chroma values (less saturation of color) than cherries heated at $113^{\circ} \mathrm{F}$. Hansen et al. (2000) also reported that methyl bromide fumigated cherries had less green colored stems than nonfumigated controls.

Cherries heated at $113^{\circ} \mathrm{F}$ had lower TA than control or fumigated fruit (Table 1). However, the TA of cherries heated at $117^{\circ} \mathrm{F}$ was similar to fumigated and control fruit. Neven and Drake (2000) observed similar effects on the TA when cherries were exposed to 113 or $117^{\circ} \mathrm{F}$. The lower TA of cherries exposed to $113{ }^{\circ} \mathrm{F}$ relative to $117^{\circ} \mathrm{F}$ could be due to longer exposure to heat at fruit center temperatures between 104 and $112^{\circ} \mathrm{F}$, suggesting fruit respiration is still active at these temperatures.

Heated and fumigated cherries were rated similar to control cherries by preference panelists (Table 1). Incidence of pitting, bruising, and decay, as well as SSC and fruit color were not affected by heating or methyl bromide fumigation.

Cooling method after heating influenced cherry stem color, with cherries hydrocooled after heating having superior quality stems than cherries cooled by forced or static air. Cherries hydrocooled after heating had lighter stems $(\mathrm{L}=40.9)$ with more color saturation (chroma $=12.0$ ) than cherries cooled in forced, cold-air (38.6 and 10.7 , respectively) or ambient, static-air (39.5 and 10.7, respectively). No other measured quality attribute was affected by cooling method after heating. Nei- ther hydrocooling before heating, nor atmosphere during cold storage had any effect on quality after $14 \mathrm{~d}$ of cold storage (data not shown).

Results from this research suggest that 'Bing' sweet cherries tolerate a short exposure to $1 \% \mathrm{O}_{2}$ and $15 \% \mathrm{CO}_{2}$ at 113 or $117^{\circ} \mathrm{F}$. The tolerance of the cherries to the heat treatments evaluated in this research was superior to that reported by Neven and Drake (2000), suggesting need for further investigation of heating rate, and sequence of heat and atmosphere application on fruit tolerance and insect mortality. Hydrocooling cherries before or after heating had no deleterious effect on fruit quality, and may be beneficial to preservation of cherry stem color.

\section{Literature cited}

Drake, S.R., H.R. Moffit, and E.M. Kupferman. 1991. Quality characteristics of 'Bing' and 'Rainier' sweet cherries treated with gibberellic acid, following fumigation with methyl bromide. J. Food Quality 14:119-125.

Hansen, J.D., S.R. Drake, H.R. Moffitt, D.J.Albano, and M.L. Heidt. 2000. Methyl bromide fumigation of five cultivars of sweet cherries as a quarantine treatment against codling moth. Hort Technology 10 (1):194198.

Neven, L.G. and E.J. Mitcham. 1996. CATTS (Controlled Atmosphere/Temperature Treatment System): A novel tool for the development of quarantine treatments. Amer. Entomol. 42:56-59.

Neven, L.G. and S.R. Drake. 2000. Comparison of alternative postharvest quarantine treatments for sweet cherries. Postharvest Biol. Technol. 20:107-114.

Shellie, K.C., R.L. Mangan, and S.J. Ingle. 1997. Tolerance of grapefruit and mexican fruit fly to heated controlled atmospheres. Postharvest Biol. Technol. 10:179-186.

Soderstrom, E.L., D.G. Brandl, and B. Mackey. 1990. Responses of codling moth (Lepidoptera: Tortricidae) life stages to high $\mathrm{CO}_{2}$ or low $\mathrm{O}_{2}$ atmospheres. J. Econ. Entomol. 83:22-27.

United Nations Environmental Programme. 1992. Methyl bromide: Atmospheric science, technology \& economics. U.N. Headquarters, Ozone Secretariat. Nairobi, Kenya.

U.S. Department of Agriculture. 1999. Use of methyl bromide for quarantine and preshipment. Methyl Bromide Alternatives Nwslt. 5(4):3-5. 